\title{
Biospeciation of tungsten in the serum of diabetic and healthy rats treated with the antidiabetic agent sodium tungstate
}

\author{
M. Milagros Gómez-Gómez ${ }^{\mathrm{a}, *}$, Nuria Rodríguez-Fariñas ${ }^{\mathrm{b}}$, Benito Cañas-Montalvo ${ }^{\mathrm{a}}$, \\ Jorge Domínguez ${ }^{\mathrm{c}}$, Joan Guinovart ${ }^{\mathrm{c}}$, Carmen Cámara-Rica ${ }^{\mathrm{a}}$ \\ a Department of Analytical Chemistry, Faculty of Chemistry, University Complutense of Madrid, 28040 Madrid, Spain \\ b Department of Analytical Chemistry and Food Technology, Faculty of Environmental Sciences, University of Castilla-La Mancha, 45071 Toledo, Spain \\ ${ }^{\mathrm{c}}$ Department of Biochemistry and Molecular Biology and IRB Barcelona, Barcelona Science Park, University of Barcelona, 08028 Barcelona, Spain
}

\section{A R T I C L E I N F O}

\section{Article history:}

Received 3 December 2010

Received in revised form 21 February 2011

Accepted 25 February 2011

Available online 4 March 2011

\section{Keywords:}

Tungsten biospeciation

Diabetes

Rat serum

SEC-ICP-MS

MALDI-TOF

\begin{abstract}
A B S T R A C T
It is known that oral administration of sodium tungstate preserves the pancreatic beta cell function in diabetic rats. Healthy and streptozotocin-induced diabetic rats were treated with sodium tungstate for one, three or six weeks, after which the species of $\mathrm{W}$ in serum, were analysed. An increase in serum $\mathrm{W}$ with treatment time was observed. After six weeks, the serum $\mathrm{W}$ concentration in diabetic rats $\left(70 \mathrm{mg} \mathrm{L}^{-1}\right)$ was about 4.6 times higher than in healthy specimens. This different behaviour was also observed for $\mathrm{Cu}$ accumulation, while the $\mathrm{Zn}$ pattern follows the contrary. The patterns observed in the retention of $\mathrm{Cu}$ and Zn may be attributable to a normalization of glycaemia. The speciation analysis of $\mathrm{W}$ was performed using 2D separations, including an immunoaffinity packing and a SEC (Size Exclusion Chromatography) column coupled to an ICP-MS (Inductively Coupled Plasma Mass Spectrometry) for elemental detection. Ultrafiltration data together with SEC-ICP-MS results proved that around $80 \%$ of serum $\mathrm{W}$ was bound to proteins, the diabetic rats registering a higher $\mathrm{W}$ content than their healthy counterparts. Most of the proteinbound $\mathrm{W}$ was due to a complex with albumin. An unknown protein with a molecular weight higher than $100 \mathrm{kDa}$ was also found to bind a small amount of W (about 2\%). MALDI-TOF (Matrix-Assisted Laser Desorption Ionization Time-of-Flight) analysis of the desalted and concentrated chromatographic fractions confirmed albumin as the main protein bound to tungstate in rat serum, while no binding to transferrin (Tf) was detected. The interaction between glutathione and $\mathrm{W}$ was also evaluated using standard solutions; however, the formation of complexes was not observed. The stability of the complexes between $\mathrm{W}$ and proteins when subjected to more stringent procedures, like those used in proteomic methodologies (denaturing with urea or SDS, boiling, sonication, acid media, reduction with $\beta$-mercaptoethanol (BME) or DTT (dithiotreitol) and alkylation with iodoacetamide (IAA), was also evaluated. Our results indicate that the stability of the complexes between $\mathrm{W}$ and proteins is not too high enough to remain unaltered during protein separation by SDS-PAGE in denaturing and reducing conditions. However, the procedures for in-solution tryptic digestion and for ESI-MS analysis in $\mathrm{MeOH} / \mathrm{H}_{2} \mathrm{O} /$ with $0.1 \%$ formic acid could be used for protein identification without large loss of binding between $\mathrm{W}$ and proteins.
\end{abstract}

Crown Copyright ( $\odot 2011$ Published by Elsevier B.V. All rights reserved.

\section{Introduction}

Diabetes mellitus is considered a major public health concern. In 2008 this disease affected 180 million people worldwide, and this figure is expected to rise to 366 million by 2030. In spite of the introduction of hypoglycaemic drugs, diabetes and related complications (neuropathy, nephropathy, retinopathy and poor circulation) continue to be a major medical problem. Consequently, considerable research effort is devoted to the development of new

\footnotetext{
* Corresponding author.

E-mail address: mmgomez@quim.ucm.es (M.M. Gómez-Gómez)
}

pharmacological agents for the treatment of diabetes. Recently, several inorganic elements, including derivates of vanadium [1], molybdenum [2], cobalt [3] and zinc [4], that mimic the effects of insulin or increase the action of this hormone have been proposed for the treatment of this disease. Indeed, oral administration of sodium tungstate has recently emerged as an effective treatment for diabetes [5]. This treatment does not cause significant undesirable side effects and furthermore this compound presents a low toxicity profile [5]. The effect of tungstate is partly due to normalization of the activity of sucrase and SGLT1 in the brushborder membrane of enterocytes [6]. Moreover, several long-term treatments with tungstate in animal models of diabetes normalize glycaemia by restoring hepatic glucose metabolism [5]. 
Streptozotocin (STZ)-induced diabetes in rats is an interesting model because it triggers insulinopenic diabetes, which, as in human type 1 diabetes [7], involves the impairment of the immune system. Type 1 diabetes results from the selective destruction of insulin-producing beta cells in pancreatic islets [8]. The protective effect of tungstate on SZT-induced pancreatic damage has been demonstrated in rats [9]. Furthermore, in this animal, female reproductive function, which is impaired in insulin-dependent diabetes [10], is alleviated by a 12-week tungstate treatment, causing partial recovery of libido and a significant improvement in reproductive performance [11]. In addition, tungstate treatment causes a dramatic decrease in body weight in healthy and diabetic rats [5]. It is known that excessive body weight is implicated in the origin of type 2 diabetes.

Biospeciation analysis involves highly complex analytical methodologies that should have the capacity to overcome drawbacks such as low concentrations, complex matrices, species transformations, and cleavage of the metal-biomolecule bonds. In general, the complexity of the clinical samples makes it necessary to perform prior fractionation/separation steps for the isolation of metal-biomolecule complexes [12]. Recent years have witnessed the introduction of complementary analytical techniques, like tandem HPLC-ICP-MS, for the separation of the metal-containing species and on-line high sensitive detection of the metal, and structural Mass Spectrometry (MS) techniques, such as MALDI-TOF and Electrospray Ionization (ESI)-MS [13,14].

A HPLC-ICP-MS method for W speciation in protein model solutions and in spiked human serum has been described [15]. W showed a high tendency to be retained in the chromatographic columns. Size Exclusion Chromatography (SEC) coupled to ICPMS with a Phenomenex Bio-SepS 2000 column, and $150 \mathrm{mM} \mathrm{NaCl}$ in $20 \mathrm{mM}$ HEPES pH 7.4 as mobile phase, provided quantitative recovery of $\mathrm{W}$ species from the column and was chosen to screen for $\mathrm{W}$-protein species and free $\mathrm{W} . \mathrm{W}$ in protein model solutions forms complexes with albumin and, to a lesser extent, with apotransferrin (apo-Tf) following a fast kinetic process that is not quantitative. Conversely, there is no interaction between $\mathrm{W}$ and immunoglobulin-G (IgG) or $\alpha_{2}$-macroglobulin. In vitro studies with spiked human serum revealed the formation of $\mathrm{W}$-albumin complex (45\%) and a significant amount of free W (30-40\%). These results are in contrast with those reported for antidiabetic $\mathrm{V}^{\mathrm{IV}} \mathrm{O}$ compounds when orally administrated and show Tf as the main $\mathrm{V}^{\mathrm{IV}} \mathrm{O}$ transporter in serum in vivo. This association was independent of the chemical form in which $\mathrm{V}^{\mathrm{IV}} \mathrm{O}$ was administered [16].

To understand the transport and metabolism of $\mathrm{W}$ in animal models, a biospeciation study of this element in serum from diabetic and healthy rats after oral intake of sodium tungstate for diabetes treatment have been done. Several analytical approaches based on the use of 2D separations by SEC-ICP-MS, ultrafiltration and immunoaffinity, and MALDI-TOF to characterize the protein moieties associated with $W$ fractions of the serum were done. The strength of the bonds between $\mathrm{W}$ and proteins when subjected to high denaturing procedures, like those employed in proteomic analysis, was also evaluated.

\section{Experimental}

\subsection{Reagents and materials}

All chemicals were of analytical grade. All solutions were prepared in de-ionised water (Milli-Q Ultrapure water systems, Millipore, USA). Standard solutions were prepared from stock solutions of $\mathrm{W}, \mathrm{Cu}, \mathrm{Zn}, \mathrm{Rh}, \mathrm{Pt}$ and $\operatorname{Ir}\left(1000 \mathrm{mg} \mathrm{L}^{-1}\right.$, Merck), diluted with $5 \% \mathrm{HNO}_{3}$ to the concentrations required. Human serum albumin (HSA), reduced L-glutathione (GSH), iodoacetamide (IAA), dithiotreitol (DTT), urea, sodium dodecyl sulfate (SDS) and $\beta$ mercaptoethanol (BME) were purchased from Sigma Aldrich. Tris(hydroxymethyl)aminomethane (Tris), trifluoracetic acid (TFA) and formic acid $(\mathrm{HCOOH})$ were from Fluka. HPLC grade acetonitrile $(\mathrm{ACN})$ and methanol $(\mathrm{MeOH})$ were purchased from Scharlab. The HPLC mobile phase used was a $20 \mathrm{mM}$ [4-(2-hydroxyethyl)piperazine-1-(2ethanesulfonic acid)] (HEPES) buffer ( $\mathrm{pH} 7.4$ ) (Sigma-Aldrich) with $150 \mathrm{mM} \mathrm{NaCl}$ (Panreac). High-purity nitric acid and hydrochloric acid, used for $\mathrm{pH}$ adjustment of the chromatographic mobile phase and other buffers, were obtained by distillation of the analytical grade reagents (Merck). Sinapinic acid (Fluka), TFA and ACN were used for MALDI-TOF analysis. Microcon YM centrifugal devices (3, 10, 30, 50 and $100 \mathrm{kDa}$ cut-off filters) were purchased from Millipore. A 5804 R centrifuge (Eppendorf), a dry bath for Eppendorf heating (Labnet International), a sonication bath (Selecta) and a pH-meter (Crison) were used.

\subsection{Animals and treatment protocols}

Adult female Wistar rats $(200 \mathrm{~g})$ were housed at $22^{\circ} \mathrm{C}$ in a lightcontrolled (12-h cycle) animal facility and had free access to food and water. When stated, diabetes was induced by a single intraperitoneal injection of STZ ( $70 \mathrm{mg} \mathrm{kg}^{-1}$ of body weight) in $0.9 \% \mathrm{NaCl}$ with $100 \mathrm{mM}$ sodium citrate buffer ( $\mathrm{pH} 4.5$ ). Diabetes was confirmed by measuring glycemia. Diabetic rats were used 5-7 days after STZ injection, when serum glucose exceeded $500 \mathrm{~g} \mathrm{~L}^{-1}$. Diabetic and healthy rats were divided into two groups. The first group (untreated) received drinking water, while the second (treated) received a solution of $2 \mathrm{~g} \mathrm{~L}^{-1}$ sodium tungstate in water. Fluid and food intakes as well as body weight were controlled regularly for 1,3 and 6 weeks. At the end of the experiments, rats were anesthetized with diethyl ether and decapitated between 9.00 and 10.00 am. Blood was collected immediately and the serum was separated from coated cells by centrifugation.

Animals were handled following the guidelines of the National Council for Care of Laboratory Animals.

\subsection{Analysis of $W, C u$ and $Z n$ by ICP-MS}

A quadupole ICP-MS Thermo X-Series (Thermo Electron) equipped with a Meinhard nebulizer for slurry analysis $(\varnothing 150 \mu \mathrm{m})$, a Fassel torch and an impact bead quartz spray chamber cooled by a Peltier system was used for $\mathrm{W}, \mathrm{Zn}$ and $\mathrm{Cu}$ determination. ICPMS operating conditions were as follows: forward power $1250 \mathrm{~W}$, plasma gas $15 \mathrm{~L} \mathrm{~min}^{-1}$, auxiliary gas $0.73 \mathrm{~L} \mathrm{~min}^{-1}$, nebulizer gas $0.85 \mathrm{~L} \mathrm{~min}^{-1}$, channels per AMU 10 and integration time $0.6 \mathrm{~ms}$. Sample was introduced in continuous mode and single-ion monitoring of $\mathrm{m} / \mathrm{z} 184(\mathrm{~W}), 186(\mathrm{~W}), 65$ (Cu), 66 (Zn) and 191 (Ir) was used to collect data. Before analysis, serum samples were centrifuged at $12,000 \times \mathrm{g}$ at $4{ }^{\circ} \mathrm{C}$ for $5 \mathrm{~min}$ and the supernatants were diluted with $2 \%(\mathrm{v} / \mathrm{v}) \mathrm{HNO}_{3}$ for analysis. Quantification was performed using external calibration in a working range between 50 and $1200 \mu \mathrm{g} \mathrm{L}^{-1}$. We used $250 \mu \mathrm{g} \mathrm{L}^{-1}$ of Ir as internal standard.

\subsection{W speciation by SEC-ICP-MS}

Speciation studies were performed using a LC-ICP-MS hyphenated system. A high pressure quaternary gradient pump (Jasco PU-2089) equipped with a 200- $\mu \mathrm{L}$ sample injection valve (Rheodine) was used as the delivery system. Two types of SEC column were used to separate the proteins bound to $\mathrm{W}$ : (a) Phenomenex Bio-Sep-S 2000 (Pharmacia Biotech), with a separation range of 1-300 kDa, and (b) Superdex 75 10/300 column (Pharmacia Corporation, $300 \times 7.8 \mathrm{~mm}$ id), with a separation range $3-70 \mathrm{kDa}$. The flow rates were 1 and $0.8 \mathrm{~mL} \mathrm{~min}^{-1}$, respectively. Serum samples were diluted 10-50-fold with the mobile phase (HEPES buffer $\mathrm{pH}$ 
Table 1

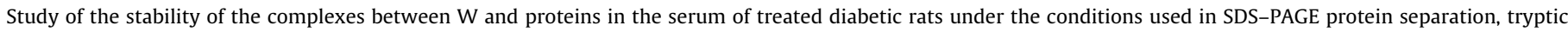
digestion and ESI-MS analysis. Results are presented as the percentage of recovery from the original W-protein fraction after ultrafiltration.

\begin{tabular}{|c|c|c|c|c|}
\hline \multirow[b]{2}{*}{ Treatment } & \multirow{2}{*}{$\begin{array}{l}\text { Break-through fraction } \\
\text { W-inorganic } \\
\left(\mathrm{mg} \mathrm{L}^{-1}\right)\end{array}$} & \multirow{2}{*}{$\begin{array}{l}\text { Retained fraction } \\
\text { W-proteins } \\
\left(\mathrm{mg} \mathrm{L}^{-1}\right)\end{array}$} & \multicolumn{2}{|l|}{ \% Recovery } \\
\hline & & & W-proteins & Total W \\
\hline Raw sample & - & 12.3 & 100 & 100 \\
\hline $1 \%$ SDS + 62.5 mM Tris- $\mathrm{HCl}(\mathrm{pH} 6.8)$ & 3.1 & 8.7 & 76 & 96 \\
\hline $1 \% \mathrm{SDS}+62.5 \mathrm{mM}$ Tris-HCl (pH 6.8), UW (10 min) & 4.7 & 2.7 & 22 & 60 \\
\hline $1 \% \mathrm{SDS}+62.5 \mathrm{mM}$ Tris- $\mathrm{HCl}(\mathrm{pH} 6.8), 100^{\circ} \mathrm{C}(5 \mathrm{~min}), \mathrm{UW}(10 \mathrm{~min})$ & 4.9 & 1.2 & 10 & 49 \\
\hline $1 \% \mathrm{SDS}+62.5 \mathrm{mM}$ Tris- $\mathrm{HCl}(\mathrm{pH} 6.8)+5 \% \mathrm{BME}$ & 4.1 & 2.0 & 17 & 49 \\
\hline $1 \% \mathrm{SDS}+62.5 \mathrm{mM}$ Tris $-\mathrm{HCl}(\mathrm{pH} 6.8)+5 \% \mathrm{BME}, 100^{\circ} \mathrm{C}(5 \mathrm{~min}), \mathrm{UW}(10 \mathrm{~min})$ & 2.4 & 2.5 & 22 & 40 \\
\hline $70 \% \mathrm{ACN}+0.1 \% \mathrm{HCOOH}$ & 0.81 & 2.8 & 24 & 29 \\
\hline $50 \%$ ACN & 0.78 & 4.2 & 36 & 40 \\
\hline $50 \% \mathrm{MeOH}$ & 0.83 & 8.9 & 78 & 79 \\
\hline $0.1 \% \mathrm{HCOOH}$ & 1.3 & 7.2 & 62 & 68 \\
\hline $50 \% \mathrm{ACN}+0.1 \% \mathrm{HCOOH}$ & 0.76 & 2.4 & 21 & 26 \\
\hline $50 \% \mathrm{MeOH}+0.1 \% \mathrm{HCOOH}$ & 0.9 & 7.4 & 64 & 67 \\
\hline $8 \mathrm{M}$ urea $+50 \mathrm{mM} \mathrm{NH}_{4} \mathrm{HCO}_{3}+10 \mathrm{mM}$ DTT $\left(37^{\circ} \mathrm{C}, 1 \mathrm{~h}\right)+50 \mathrm{mM} \mathrm{IAA}(1 \mathrm{~h})$ & 1.2 & 9.1 & 79 & 84 \\
\hline
\end{tabular}

UW: sonication.

7.4 with $150 \mathrm{mM} \mathrm{NaCl}$ ) and passed through a $0.22-\mu \mathrm{m}$ Millex GV13 filter (Millipore) before injection into the chromatographic system. For $\mathrm{W}$ detection, transient single mode was set, monitoring $\mathrm{m} / \mathrm{z}$ 184 (W) and 186 (W). $50 \mu \mathrm{g} \mathrm{L}^{-1}$ of iodide, as $\mathrm{NH}_{4} \mathrm{I}$, was used as internal standard for correction of signal drift. Quantification of both W species (organic and inorganic tungstate) was performed by external calibration of inorganic tungstate.

\subsection{Fractionation of rat serum by ultrafiltration and SEC-ICP-MS}

Rat serum was diluted 10 -fold with Milli-Q water and injected into the Superdex 75 10/300 SEC-column. The fractions with a high $\mathrm{W}$ content (8.3-10.1 $\mathrm{min}, 10.3-13.3 \mathrm{~min}$ and $19.4-21.0 \mathrm{~min}$ ) were collected in polypropylene tubes. The same fractions, from two separate runs (about $3.2 \mathrm{~mL}$ ), were pooled, filtered and concentrated by ultra filtration using centrifuge filters with molecular cut-off points of either 3, 10, 30, 50 or $100 \mathrm{kDa}$ (Amicon, Millipore). Centrifugations were made at $7500 \times \mathrm{g}, 4^{\circ} \mathrm{C}$ for $35 \mathrm{~min}$ and the samples retained were diluted with water to $250 \mu \mathrm{L}$. Both retained and break-through fractions were later analysed by SEC-ICP-MS.

\subsection{Depletion of albumin and $\operatorname{IgG}$ by immunoaffinity}

A commercially available immunoaffinity packing for albumin and IgG depletion (ProteoPrep, Sigma-Aldrich) was used. This kit contains spin columns in which ProteoPrep immunoaffinity medium is supplied in a prepacked form. Prior to use, columns are equilibrated by centrifugation $(5000 \times g)$ for $5-10 \mathrm{~s}$ to remove the storage solution, followed by two washes with $0.4 \mathrm{~mL}$ of the equilibrium buffer solution provided with the kit. Centrifugations were made for $5-10 s$ at $5000 \times g$. Buffer in the collection tube was discarded and the spin column was place in a fresh collection tube. Aliquots of $50 \mu \mathrm{L}$ of serum sample were diluted to $100 \mu \mathrm{L}$ with the equilibration buffer and added to the top of the packed medium bed. The sample was immediately adsorbed into the medium, thus ensuring efficient binding of albumin and IgG and minimal sample dilution. Spin columns were incubated at room temperature for $5-10 \mathrm{~min}$ and centrifuged at $8000 \times \mathrm{g}$ for $60 \mathrm{~s}$. To ensure optimal depletion of abundant proteins, the eluate was reapplied to the top of the spin column, incubated for another 5-10 min and centrifuged again for $60 \mathrm{~s}$ using the same collection tube. The proteins that remained unbound were washed from the column by adding $125 \mu \mathrm{L}$ of the equilibration buffer and were then centrifuged for 60 s. Finally, the albumin- and IgG-depleted serum was analysed by SEC-ICP-MS.

\subsection{Elucidation of protein $M_{r}$ by MALDI-TOF-MS}

Mass analyses of proteins that potentially bind to $\mathrm{W}$ were performed by MALDI-TOF (Voyager DE-PRO, Applied Biosystems). Fractions eluting from the SEC column at 10.3-13.3 min were collected in polypropylene tubes. A pool of identical fractions from two separate runs were desalted and concentrated in cut-off filters of $30 \mathrm{kDa}$ by centrifugation at $5000 \times g$ and $4{ }^{\circ} \mathrm{C}$ for $1 \mathrm{~h}$. The retentate was made up to $100 \mu \mathrm{L}$ with ultrapure water. These aliquots were mixed with a saturated sinapinic acid solution in $0.1 \%(\mathrm{v} / \mathrm{v})$ TFA: ACN to measure the molecular mass of proteins by MALDITOF. The operating parameters used were as follows: detector, linear mode; accelerating voltage, $25 \mathrm{kV}$; grid, $95 \%$; guide wire, 0.2 ; delay time, $500 \mathrm{~ns}$. Acquisition was made in the $m / z$ range between 30,000 and $75,000 \mathrm{kDa}$. A total of 100 shots were made per spectrum, and six spectra were accumulated per sample in order to increase the $S / N$ ratio. Spectra were acquired in positive ion mode. The analysis was performed by external calibration of the instrument by placing several aliquots of a standard solution of human serum albumin $\left(M_{r} 66,554\right)$ in alternative holes of the MALDI plate.

\subsection{Incubation of glutathione with $W$}

A solution of $500 \mu \mathrm{M}$ GSH was incubated with sodium tungstate ( $10 \mathrm{mg} \mathrm{L}^{-1}$ as $\mathrm{W}$ ) at $37^{\circ} \mathrm{C}$ for, $2,4,24,48,144$ and 360 and $480 \mathrm{~h}$ in two saline solutions: (a) $5 \mathrm{mM} \mathrm{NaCl}$ in a $20 \mathrm{mM}$ HEPES buffer at $\mathrm{pH}$ 7.4 and (b) $25 \mathrm{mM} \mathrm{NaCl}$ in a $20 \mathrm{mM}$ Tris- $\mathrm{HCl}$ buffer at $\mathrm{pH} 7.4$. The analyses of these solutions after the incubations were performed by SEC-ICP-MS.

\subsection{Stability of the complexes between tungstate and proteins}

Aliquots of $40-\mu \mathrm{L}$ of rat serum samples were diluted to $250 \mu \mathrm{L}$ with the chromatographic mobile phase. The $\mathrm{W}$ bound to proteins was isolated from the unbound fraction by ultrafiltration with a $10 \mathrm{kDa}$ cut-off filter and centrifugation $(14,000 \times \mathrm{g})$. The retained fraction (about $40 \mu \mathrm{L}$ ) was recovered and subjected to one or more of the treatments shown in Table 1 , such as denaturing with urea, heating, sonication, acid media, reduction of disulfide bonds with BME, and blocking of the free thiols generated by alkylation with IAA. After these treatments, samples were ultrafiltrated again and the retained and filtrated solutions were analysed by FI-ICP-MS. 


\section{Results and discussion}

\subsection{W accumulation in diabetic and healthy rats after treatment} with sodium tungstate

The concentration of $\mathrm{W}$ in the serum of treated rats increased with the treatment time (Table 2). As a general trend a more pronounced increased of $\mathrm{W}$ in serum from diabetic than for healthy rats was observed. The ratios of $\mathrm{W}$ content for diabetic compared to healthy rats were 3.2-, 2.7- and 4.6-fold after 1, 3 and 6 weeks of treatment, respectively. Diabetes induces a great intake of water. Consequently, for an appropriate evaluation of the accumulation of $\mathrm{W}$, along with the weight of the rats, the amount of $\mathrm{W}$ ingested during the treatment must be taken into consideration. The average amount of tungstate ingested in the 6-week treatment was $623 \pm 114 \mathrm{mg} \mathrm{kg}^{-1}$ day $^{-1}$ and $205 \pm 25 \mathrm{mg} \mathrm{kg}^{-1}$ day $^{-1}$ for diabetic and healthy rats, respectively. These figures imply that diabetic rats ingested 3 times more tungstate than their healthy counterparts, thus accounting for the higher $\mathrm{W}$ concentration found.

Administration of sodium tungstate to diabetic rats normalized glycemia. No undesirable side-effects were detected and a general good state of health was observed. Moreover, these rats showed a significant loss of body weight. This effect could be considered an additional benefit of the treatment as it is known that body weight gain is one of the factors involved in diabetes mellitus type 2. Tungstate treatment did not modify daily food and water consumption habits in healthy rats, although a significant decrease was observed in diabetic ones, reaching values that were only slightly greater than those observed for treated and untreated healthy rats.

Given that $\mathrm{Cu}$ and $\mathrm{Zn}$ are involved in glucose metabolism, the content of these metals in the serum of the four experimental sets after 6 weeks treatment was evaluated. The concentration of $\mathrm{Cu}$ was 2.4-fold higher in diabetic than in healthy ones (Table 2). These results may be explained by the fact that $\mathrm{Cu}$ is crucial for the catalytic activity of the enzymes cytochrome $C$ oxidase and superoxide dismutase, both thought to be involved in diabetes as a result of their participation in the regulation of intracellular redox status. An increase in $\mathrm{Cu}$ concentration has been reported in the liver and kidney of STZ-diabetic rats [17] and has been linked to diabetes [18]. Abnormalities in Cu metabolism appear to be a consequence of the disease.

Insulin is produced in the $\beta$-cells of the pancreatic islets as a hexamer around $\mathrm{Zn}$. Patients with diabetes suffer from hypozincemia as a result of failure of $\beta$-cell production, which finally affects insulin levels [19]. Our results are consistent with this finding as we detected a 1.8-fold higher Zn concentration in healthy rats than in diabetic ones after sodium tungstate treatment (Table 2 ).

\subsection{W speciation by SEC-ICP-MS}

Here we applied methodology previously reported [15] to test the speciation of $\mathrm{W}$ in the serum of diabetic and healthy rats treated with sodium tungstate for 1,3 and 6 weeks. Fig. 1c shows the chromatogram obtained by SEC-ICP-MS, using a SEC column Phenomenex Bio/Sep 2000 with a separation range of 1-300 kDa, from a serum sample of a diabetic rat treated for 6 weeks. The comparison of this chromatogram with those obtained with tungstate standards (1b) and a solution of albumin incubated in vitro with tungstate (1a), allows the assignation of the two main peaks observed: at 6.6 min the complex $\mathrm{W}$-albumin and at 9.5 min free $\mathrm{W}$. In a previous work quantitative column recoveries for the $\mathrm{W}$ species were obtained [15]. To improve the chromatographic resolution, a SEC column with a separation range between 3 and $70 \mathrm{kDa}$ was tested (a Superdex 75 10/300). Fig. 2c shows the chromatogram obtained for this column, where three peaks were observed in the chromatogram of a same serum sample. The main peak at $11.3 \mathrm{~min}$

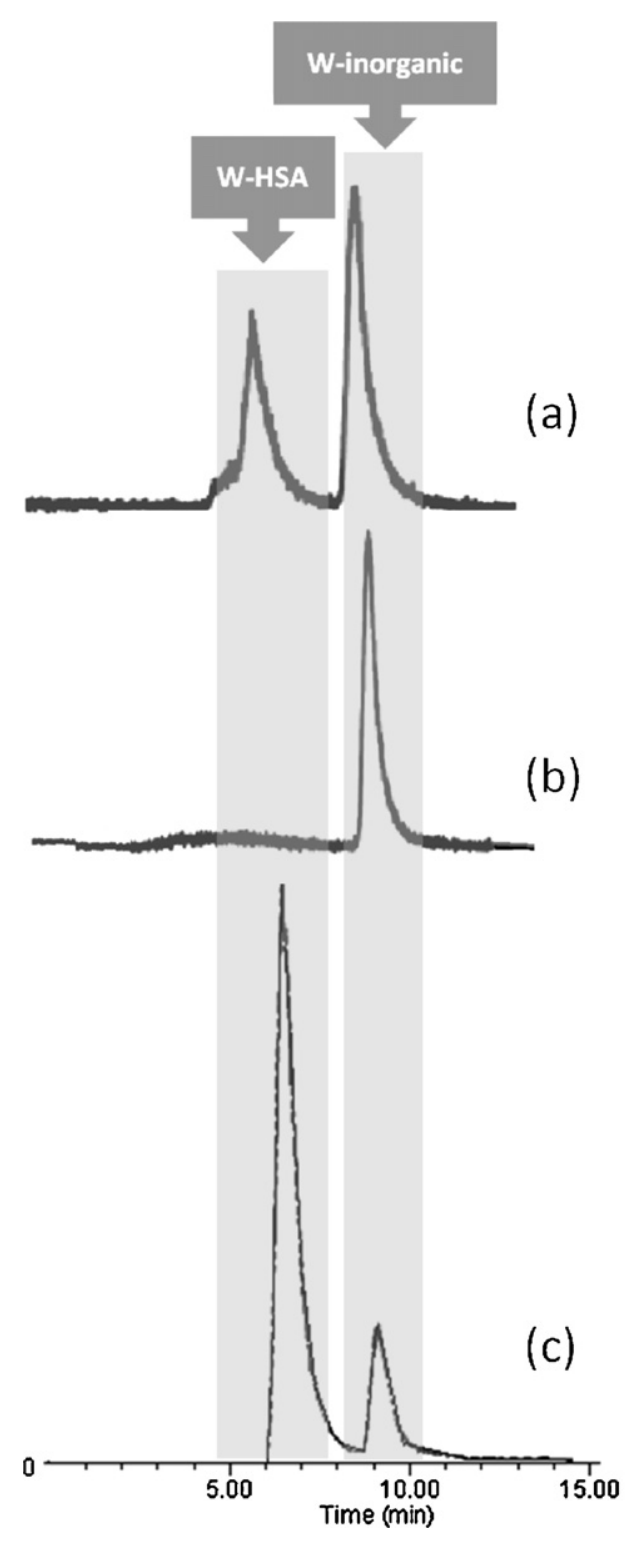

Fig. 1. SEC-ICP-MS chromatograms obtained with a column Phenomenex Bio/Sep 2000 (1-300 kDa) of: (a) a standard solution of $5 \mathrm{mg} \mathrm{L}^{-1} \mathrm{HAS}$ incubated with $5 \mu \mathrm{g} \mathrm{L}^{-1}$ tungstate in $0.9 \% \mathrm{NaCl}$ and $10 \mathrm{mM}$ HEPEs buffer ( $\mathrm{pH}$ 7.4) for $2 \mathrm{~h}$, (b) $5 \mu \mathrm{g} \mathrm{L}^{-1}$ tungstate and (c) a serum of a diabetic rat treated for 6 weeks with sodium tungstate.

matches the $\mathrm{W}$-albumin complex while that at 20.2 min matches free W. However, the new small peak at 9.2 min does not match any of the previously characterized $\mathrm{W}$ compounds, and corresponds to a W-protein species with a higher molecular weight than albumin that elutes in the column exclusion volume. The same chromatographic profile for a healthy rat treated with tungstate for six weeks was obtained (Fig. 2b). Secondary interactions of the species with the stationary phase may explain the higher resolution obtained with this column, as compared to the Phenomenex Bio/Sep 2000 column, for the separation of W-serum protein complexes. Quantitative recoveries for both columns were obtained.

For the quantification of free $\mathrm{W}$ and protein-bound $\mathrm{W}$ species by SEC-ICP-MS, the use of an internal standard that corrects for potential instrumental drifts in the analysis, especially in the case of mobile phases with high saline content, is recommended. Solutions of $\mathrm{Pt}, \mathrm{Rh}, \mathrm{Ir}$ and $\mathrm{NH}_{4} \mathrm{I}$ were diluted in the chromatographic mobile phase and tested for their suitability as internal standards. Iodide that elutes at 11.6 and 25.2 min from the Phenomenex and the Superdex columns, respectively, showed the best performance 
Table 2

$\mathrm{W} \mathrm{Cu}$ and $\mathrm{Zn}$ concentrations in rat serum of diabetic and healthy rats treated with sodium tungstate for 1,3 and 6 weeks.

\begin{tabular}{|c|c|c|c|c|}
\hline Animals & Sample & {$[\mathrm{W}]\left(\mathrm{mg} \mathrm{L}^{-1}\right)$} & {$[\mathrm{Cu}]\left(\mathrm{mg} \mathrm{L}^{-1}\right)$} & {$[\mathrm{Zn}]\left(\mathrm{mg} \mathrm{L}^{-1}\right)$} \\
\hline \multicolumn{5}{|c|}{1 week of treatment } \\
\hline \multirow[t]{3}{*}{ Diabetic } & 1 & 26.9 & - & - \\
\hline & 2 & 28.1 & - & - \\
\hline & & $27.5 \pm 0.8$ & & \\
\hline \multirow[t]{3}{*}{ Healthy } & 1 & 8.1 & - & - \\
\hline & 2 & 8.8 & - & - \\
\hline & Average \pm s.d & $8.5 \pm 0.5$ & & \\
\hline \multicolumn{5}{|c|}{3 weeks of treatment } \\
\hline \multirow[t]{6}{*}{ Diabetic } & 1 & 34.0 & - & - \\
\hline & 2 & 27.2 & - & - \\
\hline & 3 & 37.5 & - & - \\
\hline & 4 & 28.0 & - & - \\
\hline & 5 & 31.0 & - & - \\
\hline & Average \pm s.d & $32 \pm 4$ & & \\
\hline \multirow[t]{5}{*}{ Healthy } & & 11.4 & - & - \\
\hline & & 12.0 & - & \\
\hline & & 12.2 & - & - \\
\hline & & 11.4 & - & - \\
\hline & Average \pm s.d & $11.7 \pm 0.4$ & - & - \\
\hline \multicolumn{5}{|c|}{6 weeks of treatment } \\
\hline \multirow[t]{5}{*}{ Diabetic } & 1 & 86 & 26.2 & 140 \\
\hline & 2 & 62 & 19.3 & 133 \\
\hline & 3 & 62 & 17.6 & 77 \\
\hline & 4 & 71 & 20.6 & 80 \\
\hline & Average \pm s.d & $70 \pm 11$ & $21 \pm 4$ & $108 \pm 33$ \\
\hline \multirow[t]{5}{*}{ Healthy } & 1 & 14.5 & 8.3 & 171 \\
\hline & 2 & 16.6 & 10.4 & 239 \\
\hline & 3 & 14.6 & 8.4 & 202 \\
\hline & 4 & 14.5 & 8.6 & 139 \\
\hline & Average \pm s.d & $15 \pm 1$ & $9 \pm 1$ & $188 \pm 43$ \\
\hline
\end{tabular}

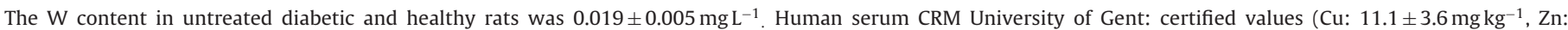
$9.6 \pm 4.2 \mathrm{mg} \mathrm{kg}^{-1}$ ). Found values (Cu: $\left.11.9 \pm 0.9 \mathrm{mg} \mathrm{kg}^{-1}, \mathrm{Zn}: 10.1 \pm 0.8 \mathrm{mg} \mathrm{kg}^{-1}\right)$.

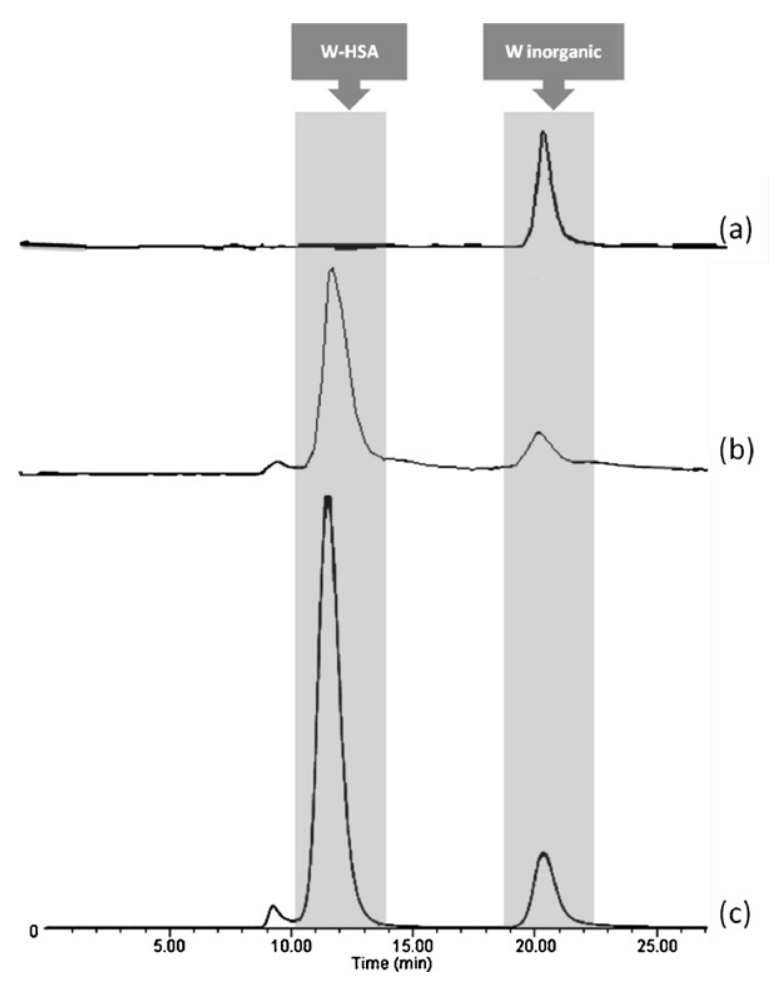

Fig. 2. Speciation of tungstate by SEC-ICP-MS with column Superdex 75 10/300 (3-70 $\mathrm{kDa}$ ) in a) $5 \mu \mathrm{g} \mathrm{L}^{-1}$ tungstate in $0.9 \% \mathrm{NaCl}$ and $10 \mathrm{mM}$ HEPEs buffer (pH 7.4), (b) a serum of a healthy rat treated for 6 weeks with sodium tungstate (c) a serum of a diabetic rat treated for 6 weeks with sodium tungstate. and was therefore selected as internal standard for subsequent analysis.

Table 3 shows the results obtained for the $\mathrm{W}$ speciation in the serum samples. The percentage of protein-bound $W$ slightly increased in healthy and diabetic rats following the treatment. Between 1 and 6 weeks, the increments were from 72 to $82 \%$ and from 52 to $66 \%$, in diabetic and healthy rats, respectively. Interestingly, the percentage of $\mathrm{W}$ bound to proteins was consistently higher for diabetic as compared to healthy rats. This fact may indicate that the treatment with tungstate induces modifications in the metabolism of albumin.

The concentration of $\mathrm{W}$ calculated by speciation (as the sum of the $\mathrm{W}$ species) was compared with the total $\mathrm{W}$ amounts obtained by direct analysis of the serum by FI-ICP-MS (Table 3 ). In general, acceptable agreement between the two values was observed, thus demonstrating the satisfactory performance of the chromatographic method used. It has to taken into account that samples arised from different animals, and this fact will be reflected in the uncertainty of the results obtained.

\subsection{Separation by ultrafiltration and SEC-ICP-MS}

Experiments were conducted to exclude the possibility of coelution of minor $\mathrm{W}$-binding proteins with complexes that are as abundant as $\mathrm{W}$-albumin complexes. Therefore, the purity of the chromatographic fractions containing $\mathrm{W}$ was first evaluated by a sequential separations through cut-off filters of 3, 10, 50 and $100 \mathrm{kDa}$, as it has been described in Section 2.5. The results obtained show that the peak at 11.3 min corresponds to a protein with a $M_{r}$ between 50 and $100 \mathrm{kDa}$, therefore, assignation to albumin-W complex is plausible, as the $\mathrm{M}_{\mathrm{r}}$ for albumin is around $66 \mathrm{kDa}$. In addition, our results show that the peak at 9.2 min corresponds to a protein bound to $\mathrm{W}$ with a $\mathrm{M}_{\mathrm{r}}$ higher than $100 \mathrm{kDa}$, and the peak at $20.2 \mathrm{~min}$ corresponds to free $\mathrm{W}$. 
Table 3

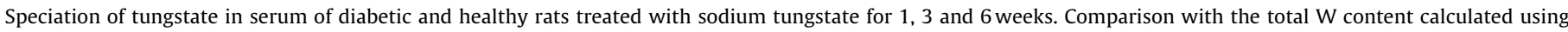
ICP-MS.

\begin{tabular}{|c|c|c|c|c|c|c|}
\hline \multirow[b]{2}{*}{ Group of animals } & \multirow[b]{2}{*}{$\begin{array}{l}\text { W-proteins } \\
\left(\mathrm{mg} \mathrm{L}^{-1}\right)\end{array}$} & \multirow[b]{2}{*}{$\begin{array}{l}\text { W-inorganic } \\
\left(\mathrm{mg} \mathrm{L}^{-1}\right)\end{array}$} & \multirow[b]{2}{*}{$\%$ W-proteins } & \multirow[b]{2}{*}{$\% \mathrm{~W}$-inorganic } & \multicolumn{2}{|c|}{ Total W $\left(\mathrm{mg} \mathrm{L}^{-1}\right)$} \\
\hline & & & & & SEC-ICP-MS & ICP-MS \\
\hline \multicolumn{7}{|c|}{ Treatment of 1 week } \\
\hline Diabetic & $14 \pm 4$ & $5.5 \pm 0.1$ & $72 \pm 20$ & $28 \pm 1$ & $20 \pm 4$ & $27.5 \pm 0.8$ \\
\hline Healthy & $3.3 \pm 0.8$ & $3.1 \pm 0.2$ & $52 \pm 12$ & $48 \pm 3$ & $6.4 \pm 0.8$ & $8.4 \pm 0.5$ \\
\hline \multicolumn{7}{|c|}{ Treatment of 3 week } \\
\hline Diabetic & $16.7 \pm 0.3$ & $9.2 \pm 0.8$ & $64 \pm 1$ & $36 \pm 3$ & $25.9 \pm 0.8$ & $31 \pm 4$ \\
\hline Healthy & $4.8 \pm 0.3$ & $6.1 \pm 0.6$ & $44 \pm 3$ & $56 \pm 6$ & $10.9 \pm 0.7$ & $11.7 \pm 0.4$ \\
\hline \multicolumn{7}{|c|}{ Treatment of 6 weeks } \\
\hline Diabetic & $55 \pm 9$ & $13 \pm 2$ & $81 \pm 13$ & $19 \pm 3$ & $68 \pm 9$ & $70 \pm 11$ \\
\hline Healthy & $10 \pm 2$ & $5.2 \pm 0.9$ & $66 \pm 13$ & $34 \pm 6$ & $15 \pm 3$ & $15 \pm 6$ \\
\hline
\end{tabular}

\subsection{D chromatographic separation by immunoaffinity and SEC-ICP-MS}

The purity of the main chromatographic peak, assigned as a W-albumin complex, was evaluated in a second approach by 2D chromatographic separation. Immunodepletion of the most abundant proteins in serum (albumin and IgG with 65\% and 15\% abundance, respectively) was used as the first chromatographic dimension. A commercially available depletion kit containing antibodies recognising albumin and IgG was used. The reported efficiency for depletion is about $95 \%$ and $85 \%$ for albumin and IgG, respectively. The depleted serum was finally subjected to the second chromatographic dimension and analysis by SEC-ICP-MS.
The main chromatographic peak at 11.3 min disappeared, while the peaks at $20.2 \mathrm{~min}$ and $9.2 \mathrm{~min}$, corresponding to free $\mathrm{W}$ and $\mathrm{W}$ complexed to the unknown-protein, remained (Fig. 3). These results confirm the purity of the $\mathrm{W}$-albumin chromatographic peak, which accounted for $80 \%$ of the $\mathrm{W}$ present in the serum of the rats after a 6 -week treatment with sodium tungstate; while the protein eluting at 9.2 min only accounts for $2 \%$. Results obtained for diabetic and healthy rats were quite similar.

\subsection{Confirmation of $W$-albumin complexes by MALDI-TOF-MS}

Given the capacity of MALDI-TOF for protein analysis, the identification of the proteins present in the $\mathrm{W}$-protein SEC fractions

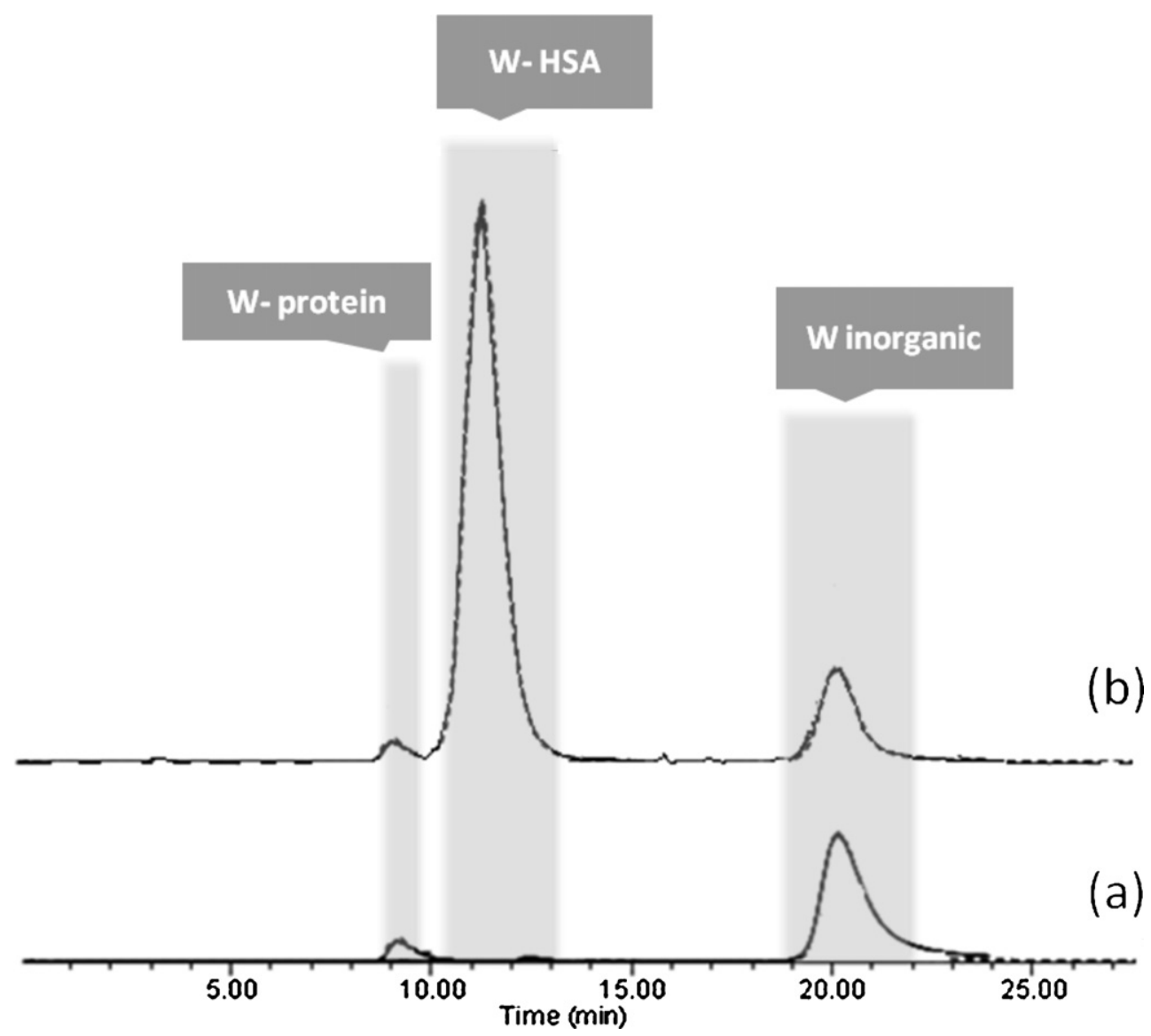

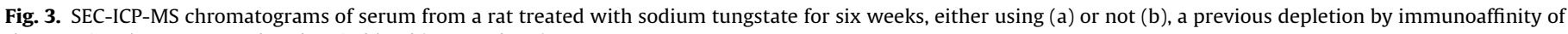
the proteins that are most abundant in blood (HSA and IgG). 
with the highest $\mathrm{W}$ content was done by MALDI-TOF. In a previous paper the formation of the tungstate-albumin complex in human serum incubated in vitro with sodium tungstate was demonstrated by MALDI-TOF analysis [15].

The mean obtained from nine different sample target spots with their standard deviations were used to calculate the $\mathrm{M}_{\mathrm{r}}$. The mass spectra from SEC fractions of samples from the four experimental groups of rats were registered. However, it should be noted that albumin gives a wide peak in MALDI-TOF, which limits the accuracy of the molecular mass obtained. The molecular ion $[\mathrm{M}+\mathrm{H}]^{+}$for the treated diabetic rats was observed at $m / z 66,859 \pm 98 \mathrm{Da}$, which is very close to the theoretical value for rat serum albumin $(65,912)$ without posttranslational modifications. The mass shift observed could be due to the glycated albumin which is elevated in the case of hygerglycemia (nowadays is used as a biomarker). No peaks were obtained for apo-Tf $(76,000)$ in this fraction. Therefore, it can be concluded that albumin is the main protein that binds to tungstate in the serum of rats following this antiabetic treatment, while no binding to Tf was observed.

\subsection{Stability of the complexes between $W$ and proteins}

Advanced metollo-proteomic analysis of $\mathrm{W}$ interaction with proteins involves the use of well established proteomic methodologies, such as SDS-PAGE and bottom-up protein identification approaches with enzymatic digestion, and final analysis of the resulting peptides by MS-MS, using either ESI or MALDI. Therefore, the evaluation of the stability of the complexes between $\mathrm{W}$ and proteins when subjected to the diverse treatments used in these methodologies is crucial. Denaturing with either urea or SDS, boiling, sonication, acid media, reduction of disulfide bonds with BME or DTT, and the alkylation reaction of the generated free thiols with IAA, were tested. Ultrafiltration with $10 \mathrm{kDa}$ cut-off filters was used to separate inorganic-W, which might be released by these treatments, from that remaining bound to proteins. Finally, both fractions were analysed by FI-ICP-MS and the results are shown in Table 1.

Sample preparation for SDS-PAGE, including SDS and BME incubation and boiling produced very low recoveries (around 10-22\%) of W bound to proteins. Nevertheless, the recovery after the incubation with Tris buffer or $1 \%$ SDS was acceptable (76\%). Consequently, we conclude that sonication, heating or reaction with BME produced deleterious effects on the binding between $\mathrm{W}$ and proteins.

When simulating the conditions used for tryptic digestion, i.e., treatment with urea, DTT, IAA within a pH range 7.5-8 in $\mathrm{NH}_{4} \mathrm{HCO}_{3}$ buffer, acceptable recoveries (79\%) were obtained.

We also tested the conditions widely used in ESI-MS. When ACN was used in the spraying solution, considerable losses of $\mathrm{W}$ from proteins were produced, while the use of $\mathrm{MeOH}$ or the $\mathrm{MeOH}$ and $0.1 \% \mathrm{HCOOH}$ mixture provided acceptable recoveries of $78 \%$ and $64 \%$, respectively.

These results suggest that the stability of the complexes between $\mathrm{W}$ and proteins is not too high enough to withstand the conditions widely applied in proteomics analysis, protein separation by SDS-PAGE in denaturing and reducing conditions. However, the procedures for in-solution tryptic digestion and ESI-MS analysis in a $\mathrm{MeOH} / \mathrm{H}_{2} \mathrm{O} /$ with $0.1 \%$ formic acid solution could be used for protein identification without large loss of the binding between $\mathrm{W}$ and proteins.

\subsection{Interaction of $W$ with glutathione}

Patients with diabetes present high levels of intracellular oxidative stress as a result of hyperglycemia and thus decreased capacity of the redox defence system. According to several diabetic models [20], oxidative stress reduces insulin secretion by the pancreas and increases insulin resistance in target tissues, while the control of glycemia results in an improved redox protective system. It has been reported that levels of GSH, an abundant antioxidant metabolite present in cells at mM level, are lower in patients suffering from diabetes [21]. Metals like $\mathrm{Cu}, \mathrm{Mn}, \mathrm{Mg}, \mathrm{Fe}, \mathrm{Se}, \mathrm{V}, \mathrm{Cr}$ and $\mathrm{Zn}$ have been proposed to indirectly participate in the reversal of oxidative stress [19], with some establishing complexes with GSH, as shown for V [22].

We evaluated the binding of W with GSH, at concentrations similar to those present inside the cells. A solution of $10 \mathrm{mg} \mathrm{L}^{-1}$ of tungstate was incubated with $500 \mu \mathrm{M}$ GSH under conditions described in Section 2.8. Experimental section and was analysed by SEC-ICP-MS. The chromatograms consistently showed only the peak corresponding to the inorganic $W$, with an area that did not vary with the incubation time (data not shown). The results suggest that the interaction between GSH and W does not occurs, as it does with other heavy metals such as Pt [23].

\section{Conclusions}

The developed analytical methodology has proven to be effective to follow the accumulation of $\mathrm{W}$ in serum in both diabetic and healthy rats after oral administration of sodium tungstate. It has been also demonstrated that albumin is the responsible protein for $\mathrm{W}$ transport after oral treatment. The strength of the bonds between $\mathrm{W}$ and proteins is not strong enough to use classical proteomic approaches like SDS-PAGE in denaturing and reducing conditions. Applications of the proposed methodology could be very useful to perform further metaloproteomic studies in cell cytosols under non-reducing SDS-PAGE and ESI-MS analysis.

\section{Acknowledgement}

This work has been supported by the research projects Santander-Complutense PR34/07-15829 and CTQ2008-01031.

\section{References}

[1] K.H. Thomson, C. Orvig, J. Inorg. Biochem. 100 (2006) 1925-1935.

[2] D.J. Ozcelikay Becker, L.N. Ongemba, A.M. Pottier, J.C. Henquin, S.M. Brichard, Am. J. Physiol. 270 (1996) E344-E352.

[3] H. Vasudevan, J.H. McNeill, Biometals 20 (2007) 129-134.

[4] G. Partida-Hernandez, F. Arrola, B. Fenton, M. Cabeza, R. Roman-Ramos, Biomed. Pharmacol. 60 (2006) 161-168.

[5] M.D. Girón, J.J. Caballero, A.M. Vargas, M.D. Suárez, J.J. Guinovart, R. Salto, FEBS Lett. 542 (2003) 84-88.

[6] M. Miro-Queralt, J.J. Guinovart, J.M. Planas, Am. J. Physiol. Gastrointest. Liver Physiol. 295 (2008) G479-G484.

[7] D.A. Rees, J.C. Alcolado, Diabetet. Med. 22 (2005) 359-370.

[8] W.Z. Hassid, S. Abrahams, in: S.P. Colowick, N. Kaplan (Eds.), Methods in Enzymology, Academy Press Co., New York, 1996, pp. 34-37.

[9] P. Yaghmaei, K. Parivar, F. Niksereshet, S. Amini, A. Masoudi, E. Amini, Diabetes Metab. Syndr. (2008), doi:10.dsx.2008/04/0101016.

[10] R. De Hertogh, I. Vanderheyden, S. Pampfer, D. Robin, J. Delcourt, Diabetologia 35 (1992) 406-408.

[11] J. Ballester, M.C. Munoz, J. Dominguez, M.J. Palomo, M. Rivera, T. Rigau, J.J. Guinovart, J.E. Rodriguez-Gil, Hum. Reprod. 22 (2007) 2128-2135.

[12] S. Mounicou, J. Szpunar, R. Lobinski, Chem. Soc. Rev. 38 (2009) 1119-1138.

[13] J. Bettmer, M. Montes Bayón, J. Ruiz Encinar, M.L. Fernández Sánchez, M.R. Fernández de la Campa, A. Sanz Medel, J. Proteomics 72 (2009) 989-1005.

[14] D. Esteban-Fernández, E. Moreno-Gordaliza, B. Cañas, M.A. Palacios, M.M. Gómez-Gómez, Metallomics 2 (2010) 19-38.

[15] N. Rodríguez-Fariñas, M.M. Gómez-Gómez, C. Cámara, Anal. Bioanal. Chem. 390 (2008) 29-35.

[16] T. Jakusch, D. Hollender, A.A. Enyedy, C. Sanchez Gónzález, M. Montes Bayon, A. Sanz Medel, J. Costa Pessoa, I. Tomaz, T. Kiss, Dalton Trans. (2009) 2428-2437.

[17] G.J. Naga Raju, P. Sarita, G.A.V. Ramana Murty, M. Ravi Kumar, B.S. Reddy, M.J. Charles, S. Lakshminarayana, T.S. Reddy, S.B. Reddy, V. Vijayan, Appl. Radiat. Isot. 64 (2006) 893-900.

[18] D. Beshgettor, M. Hambidge, Am. J. Clin. Nutr. 67 (1998) 1017S-1021S.

[19] J.A. Meyer, D.M. Spence, Metallomicas 1 (2009) 32-41. 
[20] Y.J. Suzuki, H.J. Forman, A. Sevanian, Free Radic. Biol Med. 22 (1996) 269-285.

[21] M. Rathagala, P.D. Root, D.M. Spence, Anal. Chem. 78 (2006) 8556-8560.
[22] J. Costa, I. Tornaz, T. Kiss, E. Kiss, P. Buglyo, J. Biol. Inorg. Chem. 7 (2002) 225-229.

[23] D. Esteban-Fernández, B. Cañas, I. Pizarro, M.A. Palacios, M.M. Gómez-Gómez, J. Anal. Atom. Spectrom. 22 (2007) 1113-1121. 